\title{
The Effect of Bolus Vitamin D Supplementation
}

\author{
Bolus D Vitamini Takviyesinin Etkileri
}

\author{
Sinem Bozkurt' ${ }^{1}$ Berat Meryem Alkan², Fatma Gülçin Ural², Hatice Aksekili’, Fatma Fidan², \\ Nebahat Sezer², Lale Aktekin², Özge Ardıçoğlu², Selami Akkuş² \\ ${ }^{1}$ Ankara Bilkent City Hospital, Clinic of Physical Medicine and Rehabilitation \\ ${ }^{2}$ Ankara Yıldırım Beyazıt University Faculty of Medicine, Department of PMR \\ ${ }^{3}$ Ankara Gazi Mustafa Kemal Public Hospital, Physical Medicine and Rehabilitation Clinic
}

\begin{abstract}
Objectives: Vitamin D plays an important role in musculoskeletal and nervous system health. Although, the prevalence of vitamin D deficiency is fairly high and it may lead to bone abnormalities and muscle weakness, it is a preventable condition. The aim of this prospective study was to assess the effects of vitamin D supplementation on balance, mobility, grip strength, fatigue, depression and quality of life.

Materials and Methods: Between October 1, 2015 and December 31, 2015, a total of 92 patients with vitamin D insufficiency/deficiency were included in the study. Demographic characteristics of age, gender, height, weight, serum 25-hydroxyvitamin [25-(OH)D], parathyroid hormone, alkaline phosphatase (ALP), calcium, and phosphorus levels were recorded. The primary outcome was assessed the $[25-(\mathrm{OH}) \mathrm{D}]$ levels at 1 month and 3 month post-treatment. The secondary outcomes were the efficacy of vitamin D administration on fatigue, mobility, balance, depression, quality of life (QoL), muscle strength using The Multidimensional Assessment of Fatigue Scale (MAF), Timed Up and Go Test (TUG), Single leg stance test (SLS), Beck Depression Inventory (BDI), The Nottingham Health Profile(NHP), hand dynamometer, respectively at all visits.

Results: After the 1 month, the vitamin D supplementation had significantly improved muscle strength, balance ability, mobility, QoL, depression, and fatigue symptoms. The levels of [25-(OH) D] significant decreased after 3 months.

Conclusion: Supplemental vitamin D consistently demonstrated beneficial effects on muscle strength, mobility, balance control, depression, fatigue and QoL. The 300,00o bolus of vitamin D was well-tolerated and safe in adult population. We would recommend evaluating vitamin D status once in three months.

Key words: Balance, Fatigue, Muscle strength, Quality of life, Vitamin D
\end{abstract}

\section{Öz}

Amaç: D vitamini, kas-iskelet sistemi ve sinir sistemi sağllğında önemli bir rol oynar. D vitamini eksikliği prevalansı oldukça yüksek olup kemik anormallikleri ve kas güçsüzlüğü ile sonuçlanabilmesine rağmen, önlenebilir bir durumdur. Bu prospektif çalıșmanın amacı, D vitamini desteğinin denge, mobilite, kavrama gücü, yorgunluk, depresyon ve yașam kalitesi üzerine etkilerini değerlendirmektir.

Materyal ve Metot: Çalıșmaya 1 Ekim 2015 - 31 Aralık 2015 tarihleri arasında D vitamini yetersizliği / eksiksizliği olan 92 hasta alındı. Yaş, cinsiyet, boy, kilo, serum 25-hidroksivitamin D [25- (OH) D], paratiroid hormon, alkalen fosfataz (ALP), kalsiyum ve fosfor seviyeleri kaydedildi. Primer sonuç, tedavi sonrası 1 ay ve 3 ay sonra [25- $(\mathrm{OH})$ D] seviyelerini değerlendirmekti. İkincil sonuçlar; tüm vizitlerde D vitamini uygulamasının yorgunluk, mobilite, denge, depresyon, yașam kalitesi üzerine etkinliğinin, sırasıyla Yorgunluk Ölçeğinin Çok Boyutlu Değerlendirilmesi, Zamanlı Kalk ve Yürü Testi, Tek Bacak Üzerinde Durma Testi, Beck Depresyon Envanteri, Nottingham Sağlık Profili, el dinamometresi, kullanılarak değerlendirilmesidir.

Bulgular: 1 ay sonra, D vitamini takviyesi kas gücünü, denge yeteneğini, mobiliteyi, yaşam kalitesini, depresyonu ve yorgunluk semptomlarını önemli ölçüde iyileștirdi. [25- $(\mathrm{OH}) \mathrm{D}$ ] düzeyleri düzeyleri 3 ay sonra belirgin olarak düștü.

Sonuç: D vitamini takviyesi, kas kuvveti, mobilite, denge kontrolü, depresyon, yorgunluk ve yașam kalitesi üzerinde faydalı etkiler göstermiştir. 300.ooo IU bolus D vitamini takviyesi erişkinlerde iyi tolere edilmiştir. D vitamini düzeyinin üç ayda bir değerlendirilmesini tavsiye ediyoruz.

Anahtar Kelimeler: Denge, Yorgunluk, Kas gücü, Yaşam kalitesi, D vitamini 
Yazışma Adresi / Correspondence:

Dr. Sinem Bozkurt

e-mail: sinembozkurto6@gmail.com

Date of submission: 16.05.2019

Date of admission: 13.06.2019

\section{Introduction}

Vitamin D (vit D) plays an important role in musculoskeletal and nervous system health. ${ }^{1}$

The prevalence of vit D deficiency is fairly high and it may lead to bone abnormalities and muscle weakness. ${ }^{1,2}$ In otherwise, it has also been associated with musculoskeletal pain, headache, depression, fatigue, impaired cognitive performance, cancer, heart disease, fractures and falls, autoimmune diseases. ${ }^{3-9}$ But it is a preventable condition, and the cost of prevention is inexpensive in most of the countries. ${ }^{9} \mathrm{~A}$ meta-analysis published in 2007 showed that vitamin D supplementation was associated with significantly reduced mortality. ${ }^{10}$

Sources of Vit D are sunlight, food, and supplements, with sunlight being the predominant source. Pigmented skin, sun creams with a protection factor of 15 or more, clothing that hides the face and forearms and the poor winter sun in the UK all lead to lower levels of vit D synthesis in the skin. ${ }^{2}$

Vitamin D status is usually assessed by measuring serum 25-hydroxyvitamin D [25$(\mathrm{OH}) \mathrm{D}]$ levels with most authors and Endocrine Society Clinical Practice Guideline defining adequate, insufficient, deficient, and severe deficient levels as $>75 \mathrm{nmol} / 1$ ( $>30$ $\mu \mathrm{g} / \mathrm{l}), 50-75 \mathrm{nmol} / \mathrm{l},(=21-29 \mu \mathrm{g} / \mathrm{L}), 25-49 \mathrm{nmol} / \mathrm{L}(=10-19 \mu \mathrm{g} / \mathrm{L})$, and $<25 \mathrm{nmol} / \mathrm{L}(<10$ $\mu \mathrm{g} / \mathrm{L})$, respectively. ${ }^{11-13}$

Muscle strength plays a widely recognized key role in overall functional status. However, the effects of vitamin D status on muscle function are debatable, some studies had been indicated that associations between vitamin D status and muscle strength, body sway and physical performance. ${ }^{13}$ Hand grip strength (HGS) may be used as a indicator of muscle strength and function and a clinical marker of mobility. ${ }^{13-}$ 14

Although there are many studies about the effects of vit D on muscle strength, mobility, health status, depression; most of them were observational studies and generally consisted of geriatric population and different parameters were evaluated in each study. ${ }^{15}$ The aim of this prospective study was to assess the effects of vitamin D supplementation on balance, mobility, grip strength, fatigue, depression and quality of life in adult population.

\section{Materials and Methods}

Study population

One hundred subjects who had vitamin D deficiency were recruited between October 1, 2015 and December 31, 2015 after approval from the Ethics Commitee. We followed ethical guidance which recommends adherence to the 2008 version of the Declaration 
of Helsinki. All subjects were informed verbally and written consent prior to participation.

Exclusion criteria included normal level of serum [25-(OH) D], known severe anemia, pregnant or lactating women, musculoskeletal or neurological limitations, known inflammatory conditions, thyroid dysfunctions, vestibulopathies, drugs use that could affect balance and osteoporosis, major systemic diseases such as malignancy, diabetes mellitus (DM), severe cardiopulmonary disease and metabolic bone diseases and geriatric populations (age $>65$ years).

\section{Study design}

The Chromsystems high-pressure liquid chromatography (HPLC) vitamin D2/D3 kit (Chromsystems Instruments and Chemicals GmbH, Gräfelfing, Munich, Germany) was used to measure the serum [25-(OH)D] levels of the patients. Patients with severe vit D deficiency $(<10 \mu \mathrm{g} / \mathrm{L})$ received oral vitamin D (300,00o IU) twice times per week for two weeks and patients with vit D insufficiency $(<30 \mu \mathrm{g} / \mathrm{L})$ received oral vitamin D $(150,000 \mathrm{IU})$ twice times per week for one week. The patients were evaluated before, 1 and 3 month after the replacement therapy. We collected the following data for each patient: age, gender, weight, height, serum levels of 25-OHD, parathyroid hormone, alkaline phosphatase, calcium, phosphorus, albumin, calcitonin, thyroid stimulating hormone, hemoglobin. We assessed the fatigue, mobility, balance, health status, psychological status, muscle strength at all visits and the serum levels of 25-OHD, parathyroid hormone, alkaline phosphatase, calcium, phosphorus, albumine were determined at the same time.

\section{Study measurements}

The Nottingham Health Profile (NHP) evaluates health-related quality of life related to self-perceived physical, emotional, and social health status. ${ }^{16,17}$ The validity and reliability of the Turkish version has been established Kücükdeveci et al. ${ }^{16}$ The measurement with a 'yes'/'no' answer to 38 items was composed of six sections that tested physical activity(eight items), fatigue(three items), pain(eight items), social isolation(five items), sleeping(five items) and emotional reactions(nine items). The scores were between o and 100 for each subcategory, where o indicates good health and 100 indicates poor health. Each s subcategory had different statement-scores and these statements were randomized in the measurement. ${ }^{17}$

Timed Up and Go Test (TUG Test) is a reliable, cost-effective and time-efficient way to evaluate functional mobility by measuring the time required by the subjects to do subsequent activities: standing up from a 46 centimeter-high chair with back and arm support, walking for 3 meters, turn back to the chair, and sit back. A cutoff point of 10 seconds has been applied to identify persons with an impaired mobility. ${ }^{18,19}$

Single leg stance test (SLS Test) was used for assessment of balance. Participants performed a single leg standing assessment with and without visual feed-back, balancing on their dominant leg for as long as they could without any assistance from the objects, while keeping their non-dominant leg flexed the hip and knee between $60^{\circ}$ and $90^{\circ}$ and maintain this position for 30 seconds and performed 3 additional repetitions. One minute rest period was given between trials. Average times were recorded. ${ }^{20}$ 
Grip strength was measured with a Riester hand dynamometer. ${ }^{21}$ Hand grip strength (HGS) was measured from the dominant hand while sitting, with the forearm flexed from the elbow at $90^{\circ}$ angle. Three maximal contractions lasting 3 seconds, each with one minute rest between were recorded. An average of the 3 contractions was used as the criterion score.

Beck Depression Inventory (BDI) is a self- a self-administered questionnaire which is the validated Turkish version of the 21 items in multiple-choice format. ${ }^{22,23}$ When the test is scored, a value of o to 3 is assigned for each answer and then the total score is compared to a key to determine the depression's severity. The standard cut-off scores are as follows: 0-9: indicates minimal depression ,10-18: indicates mild depression 1929: indicates moderate depression 30-63: indicates severe depression.

Fatigue was evaluated by Multidimensional Assessment of Fatigue Scale (MAF). MAF has 16 items that measure five dimensions of fatigue: degree (item 1), severity (item 2), distress (item 3), degree of interference with activities of daily living (items 4-14), and timing (items 15-16). The index score can range from 1 (no fatigue) to 50 (extreme fatigue). ${ }^{24}$

\section{Statistical Analysis}

SPSS for Windows version 22.0 software was used for all analyses (SPSS Inc., Chicago, ILL, USA). The distribution of dependent variables was examined by Pearson test. Descriptive statistics were used to describe the demographic characteristics of the patients. Time effect on variables were evaluated by paired sample t test. The level of significance was set at $\mathrm{p}<0.05$.

\section{Results}

At the beginning of the study $66.30 \%$ of the subjects had a [25- $(\mathrm{OH}) \mathrm{D}$ ] level below 10 $\mu \mathrm{g} / \mathrm{L}, 33.70 \%$ had a [25-(OH) D] level between 10 and $30 \mu \mathrm{g} / \mathrm{L}$. Any adverse events or toxicity due to therapy were documented. 8 participants was lost to follow-up. Finally, ninety-two patients aged with 20-65 years were included for the analysis. Most of the participants in our study were women (95.70\%) The demographical and clinical characteristics of subjects are shown in Table 1.

There was no significant difference between times in terms of the levels of serum albumin (Alb), calcium (Ca), phosphorus (P), alkaline phosphatase (ALP).

Supplemental vit D led to significant reductions in PTH from baseline at 4 and 12 weeks (Table 2).

The levels of [25-(OH)D], SLS and HGS scores significantly increased after the replacement therapy. However, SLS and HGS scores remains the same, levels of [25$(\mathrm{OH}) \mathrm{D}$ ] significant decreased after 3 months. Balance were similarly affected by hypovitaminosis D, independently of visual feed-back (Table 3 ).

All NHP sub-scores except for social isolation, MAF, BDI and TUG scores significantly decreased after the therapy and continued to decrease after 3 months. NHP sub-scores of social isolation tended to decrease but not statistically significant (Table 3 ). 
Table 1. Demographic and clinical characteristics of the subjects

\begin{tabular}{|l|c|}
\hline & $\begin{array}{c}\text { Subjects }(\mathbf{n}=92) \\
(\text { mean } \pm \text { SD) }\end{array}$ \\
\hline Age $($ year $)$ & $45.11 \pm 10.90(21-65)$ \\
\hline BMI $\left(\mathbf{k g} / \mathbf{c m}^{2}\right)$ & $28.32 \pm 5.11(18.7-44.4)$ \\
\hline Hb $(\mathbf{g} / \mathbf{d l})$ & $13.30 \pm 1.33(10.3-16.3)$ \\
\hline MCV & $81.66 \pm 6.60(60.9-100.7)$ \\
\hline Sedim $(\mathbf{m m} / \mathbf{h})$ & $14.10 \pm 10.61(1-47)$ \\
\hline Urea & $26.11 \pm 8.50(12-53)$ \\
\hline Creatinine & $0.66 \pm 0.12(0.4-1.2)$ \\
\hline TSH $($ Ulu/ ml) & $1.95 \pm 1.12(0.02-5.36)$ \\
\hline Calcitonin & $2.37 \pm 0.91(2-7.18)$ \\
\hline
\end{tabular}

(body mass index (BMI), hemoglobin (Hb), hematocrit (Htc), sedimentation (sedim), creatinine (Cre), thyroid stimulating hormone (TSH), Standard deviation (SD), mean corpuscular volume (MCV)

Table 2. Laboratory variables pre and post treatment.

\begin{tabular}{|c|c|c|c|c|c|c|}
\hline & $\begin{array}{c}\text { 1.visit } \\
\text { Mean } \pm \text { SD }\end{array}$ & $\begin{array}{c}\text { 2.visit } \\
\text { Mean } \pm \text { SD }\end{array}$ & $\begin{array}{c}\text { 3.visit } \\
\text { Mean } \pm \text { SD }\end{array}$ & P1 & $\mathbf{P}_{2}$ & $\mathbf{P}_{3}$ \\
\hline Alb (g/dl) & $\begin{array}{c}5.40 \pm \\
7.71 \\
\end{array}$ & $\begin{array}{c}5.86 \pm \\
8.22\end{array}$ & $\begin{array}{c}5.21 \pm \\
5.91 \\
\end{array}$ & 0.791 & 0.323 & 0.354 \\
\hline Ca $(\mathrm{mg} / \mathrm{dL})$ & $\begin{array}{c}9.42 \pm \\
0.93\end{array}$ & $\begin{array}{l}9.51 \pm \\
0.44 \\
\end{array}$ & $\begin{array}{c}9.55^{ \pm} \\
0.34\end{array}$ & 0.292 & 0.235 & 0.275 \\
\hline$P(\mathbf{m g} / \mathbf{d L})$ & $\begin{array}{c}3.53 \pm \\
0.60\end{array}$ & $\begin{array}{c}3.53 \pm \\
0.50\end{array}$ & $\begin{array}{c}3.62 \pm \\
0.60\end{array}$ & 0.684 & 0.600 & 0.352 \\
\hline $\operatorname{ALP}(\mathbf{U} / \mathbf{L})$ & $\begin{array}{c}70.72 \pm \\
19 \cdot 3 \\
\end{array}$ & $\begin{array}{c}71.34 \pm \\
18 \\
\end{array}$ & $\begin{array}{c}68.75 \pm \\
17.80 \\
\end{array}$ & 0.855 & 0.480 & 0.571 \\
\hline Vit D $(\mu \mathrm{g} / \mathrm{L})$ & $\begin{array}{c}10.65^{ \pm} \\
3.70\end{array}$ & $\begin{array}{c}40.3 \pm \\
16.1\end{array}$ & $\begin{array}{c}29.3 \pm \\
15.6 \\
\end{array}$ & $<0.001$ & $<0.001$ & $<0.001$ \\
\hline PTH $(\mathrm{pg} / \mathrm{mL})$ & $\begin{array}{c}56.20 \pm \\
23.90 \\
\end{array}$ & $\begin{array}{l}41.10 \pm \\
14.80 \\
\end{array}$ & $\begin{array}{c}41.71 \pm \\
15.20 \\
\end{array}$ & $<0.001$ & 0.076 & $<0.001$ \\
\hline
\end{tabular}

Albumine (Alb), Calcium (Ca), Phosphorus (P), Alkaline phosphatase (ALP), vitamin d (vit D), Parathyroid hormone (PTH)

* Differences between times analyzed by Paired Simple T Test, P1; $p$ value between the first visit and the second visit, $P_{2} ; p$ value between the second and the third visit, $P_{3} ; p$ value between the first visit and the third visit.

\section{Discussion}

To our knowledge, this is the first study that evaluated together with the effects of vit D supplementation on muscle strength, fatigue, balance, mobility, depression and quality of life in adult population.

25- $(\mathrm{OH}) \mathrm{D}$ seems to play an important role in the preservation of neuromuscular functions. Otherwise, the relationship between vit D and muscular strength remains yet controversial. Many studies showing lack of effect of vit D supplementation on muscle strength have been published compared to studies documenting beneficial 
effects. ${ }^{13}$ This study supported that vit D supplementation have a significant effect on muscle strength in adults. Likewise, a recently published systematic review and a meta-analysis of randomized controlled trials reported that vit D supplementation has a small but significant positive effect on muscle strength. ${ }^{25}$ Differences in populations and methodology may partly explain this inconsistency. Another explanation for incompatible results may be associated with the VDR gene polymorphisms. Some human variants appear less sensitive to vit D and more likely to develop muscle weakness. ${ }^{15}$

Table 3. Health status, fatigue, psychological status, functional mobility, balance and hand grip strength pre and post treatments

\begin{tabular}{|c|c|c|c|c|c|c|}
\hline 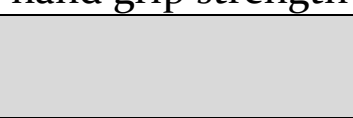 & $\begin{array}{c}\text { 1.visit } \\
\text { Mean } \pm \text { SD }\end{array}$ & $\begin{array}{c}\text { 2.visit } \\
\text { Mean } \pm \text { SD }\end{array}$ & $\begin{array}{c}\text { 3.visit } \\
\text { Mean } \pm \text { SD }\end{array}$ & $\mathbf{P 1}_{1}$ & $\mathbf{P}_{2}$ & $\mathbf{P}_{3}$ \\
\hline NHP- pain & $\begin{array}{c}58.44^{ \pm} \\
28.91\end{array}$ & $\begin{array}{c}43.40 \pm \\
26.41\end{array}$ & $\begin{array}{c}39.72 \pm \\
23.90\end{array}$ & $<0.001$ & 0.110 & $<0.001$ \\
\hline $\begin{array}{l}\text { NHP-physical } \\
\text { activity }\end{array}$ & $\begin{array}{c}31.45^{ \pm} \\
18.3^{2} \\
\end{array}$ & $\begin{array}{c}27.66 \pm \\
16.43 \\
\end{array}$ & $\begin{array}{c}24.82 \pm \\
16.70 \\
\end{array}$ & 0.024 & 0.009 & 0.004 \\
\hline NHP-fatigue & $\begin{array}{l}61.10 \pm \\
38.44\end{array}$ & $\begin{array}{l}46.24 \pm \\
38.50 \\
\end{array}$ & $\begin{array}{c}44.25 \pm \\
36.21 \\
\end{array}$ & $<0.001$ & 0.620 & 0.002 \\
\hline NHP-sleeping & $\begin{array}{c}39 \cdot 58 \pm \\
31.10\end{array}$ & $\begin{array}{c}33.93 \pm \\
29.44 \\
\end{array}$ & $\begin{array}{c}23.82 \pm \\
25.80 \\
\end{array}$ & 0.003 & 0.002 & $<0.001$ \\
\hline $\begin{array}{l}\text { NHP-social } \\
\text { isolation }\end{array}$ & $\begin{array}{c}16.95 \pm \\
26.82\end{array}$ & $\begin{array}{c}14.37 \pm \\
21.71\end{array}$ & $\begin{array}{c}10.90 \pm \\
20.21\end{array}$ & 0.461 & 0.492 & 0.710 \\
\hline $\begin{array}{l}\text { NHP- emotional } \\
\text { react }\end{array}$ & $\begin{array}{l}32.84 \pm \\
28.88 \\
\end{array}$ & $\begin{array}{l}23.95^{ \pm} \\
26.20 \\
\end{array}$ & $\begin{array}{c}20.39 \pm \\
23.90 \\
\end{array}$ & 0.001 & 0.180 & $<0.001$ \\
\hline MAF & $\begin{array}{c}30.11 \pm \\
10.25\end{array}$ & $\begin{array}{c}24 \cdot 32 \pm \\
9 \cdot 54\end{array}$ & $\begin{array}{c}21.90 \pm \\
9.25\end{array}$ & $<0.001$ & 0.210 & $<0.001$ \\
\hline BDI & $\begin{array}{c}12.23 \pm \\
8.40\end{array}$ & $\begin{array}{c}10.13 \pm \\
8.15\end{array}$ & $\begin{array}{c}8.40 \pm \\
6.70\end{array}$ & 0.001 & 0.020 & $<0.001$ \\
\hline TUG(s) & $\begin{array}{c}9.70 \pm \\
2.03 \\
\end{array}$ & $\begin{array}{r}9.11 \pm \\
1.83 \\
\end{array}$ & $\begin{array}{l}9.15^{ \pm} \\
1.60 \\
\end{array}$ & $<0.001$ & 0.460 & 0.001 \\
\hline SLS- with visual & $\begin{array}{c}24.55^{ \pm} \\
8.25\end{array}$ & $\begin{array}{c}26.10 \pm \\
7.12\end{array}$ & $\begin{array}{c}27.1 \pm \\
5.9\end{array}$ & 0.001 & $<0.001$ & $<0.001$ \\
\hline $\begin{array}{l}\text { SLS- without } \\
\text { visual }\end{array}$ & $\begin{array}{c}9.55^{ \pm} \\
7.83 \\
\end{array}$ & $\begin{array}{l}14.13 \pm \\
10.60 \\
\end{array}$ & $\begin{array}{c}14.12 \pm \\
9.80 \\
\end{array}$ & 0.001 & 0.36 & $<0.001$ \\
\hline HGS (bar) & $\begin{array}{c}0.37 \pm \\
0.10\end{array}$ & $\begin{array}{c}0.40 \pm \\
0.10\end{array}$ & $\begin{array}{c}0.40 \pm \\
0.10\end{array}$ & $<0.001$ & 0.990 & 0.005 \\
\hline
\end{tabular}

Nottingham Health Profile (NHP), Timed Up and Go Test (TUG Test)Single leg stance test (SLS Test) Hand grip strength(HGS) Nottingham Health Profile (NHP) Multidimensional Assessment of Fatigue (MAF) Paired Simple T Test, P1; $p$ value between the first visit and the second visit,, P2; $p$ value between the second and the third visit, $P_{3} ; p$ value between the first visit and the third visit.

In that study, we performed HGS measurement to evaluate muscle strength. HGS is a simple and reliable measure of muscle function and a better predictor of clinical outcomes than low muscle mass. ${ }^{26,27}$ European working group reported that isometric HGS is strongly related with lower extremity muscle power, knee extension torque and calf cross sectional muscle area. ${ }^{15}$ 
The ability to move from one position to another called functional mobility is conditioned by sensory, neuromuscular, and musculoskeletal system function, and central nervous system integration process. There are many reports indicate that vit D is involved in brain health and function. ${ }^{15,28}$ Especially, VDRs are found in almost all brain areas including structures involved in motor control and balance such as the substantia nigra, the hypothalamus and the cerebellum. ${ }^{1,15}{ }^{28}$ Based the two different studies by Pfeifer $M$ et al found that body sway is negatively correlated with vit $D$ levels. ${ }^{29,} 30$ A study by Bischoff et al showed significant functional mobility after vit D and calcium supplementation for 12 weeks similar to our study's result. ${ }^{31}$ On the other hand, in the study by Laksmi et al in elderly women aged 6o years old or above, no significant correlation was found between vit D levels and functional mobility. It is different from our study, in terms of design since it is an cross-sectional study and higher mean age (70.20) and higher vit D levels (68.0o nmol/l).The lower vit D levels, the more significant improvement could be observed after the supplementation. ${ }^{32} \mathrm{On}$ the other hand, some literatures indicated that vitamin D had positive effects on balance but lower than muscle strength improvements, while others reported no effects. ${ }^{33}, 34$ This clinical diversity can be explained by the VDR, including the brain. ${ }^{1}$

Fatigue is a state of tiredness or low energy and is the end result of underlying muscle fatigue which is more commonly seen than muscle weakness. ${ }^{35,36} \mathrm{~A}$ study of 174 patients showed that normalization of low vit D level with ergocalciferol therapy significantly improved the severity of fatigue symptoms. ${ }^{35}$ Based on another study's results, vitamin D deficiency is associated with fatigue and daytime sleepiness. ${ }^{37}$ This study also showed that a significant reduction in the fatigue scores after the therapy.

Many studies indicated that low vit D levels were related to depression..$^{7-9,37}$ On the other hand, a recent meta-analysis reported that ineffectiveness of vit D supplementation on depression. ${ }^{39}$ This conflict may be due to the differences in the reached serum vit $\mathrm{D}$ levels following interventions or the study population diversity.

The current study showed that QoL improved significantly after the vit D supplementation. Of course, muscle strength, balance, mobility, depression, fatigue effect the QoL and all this parameter improved after the therapy. Similarly, Akyüz et al reported that vit $d$ supplementation might increase the overall QoL. ${ }^{\circ}$ Many studies in various study population such as cancer, irritable bowel syndrome, diabetic neuropathy also demonstrated that vit $\mathrm{D}$ deficiency was associated with a higher severity of clinical symptoms and lower QoL.41-43

Vitamin D is one of the most cost-effective micronutrient supplements, that leads to improving overall human health. ${ }^{44}$ However, there have been controversy about the identification of the vit D deficiency and sufficiency, appropriate treatment strategy. ${ }^{45-}$ ${ }^{47}$ Severity of deficiency, body weight, sunlight exposure, skin pigmentation, dietary practices, clothing and cultural habits, and many other population-specific factors, needs to be considered in making uniform guidelines. ${ }^{46} \mathrm{~A}$ study from Indian investigated the equivalent doses of oral cholecalciferol (6o,ooo IU weekly for 5 weeks) versus intramuscular (IM) cholecalciferol (300,000 IU) in correcting Vit D deficiency and they indicated both of them are effective treatment options. ${ }^{48}$ Leventis and Kiely demonstrated that considerable efficacy and safety of oral and IM regimens utilizing a single dose of 300,00o IU vit D3 in treating vit D deficiency. 49 They concluded that the high dose bolus of vit D was practical, safe and recommended administering 300,000 
IU oral vit D3 approximately three times per year. Similarly, in this study, the therapy was well tolerated, was acceptable to patients and ensured compliance. No adverse effects was reported during the study and serum calcium levels remained within normal limits in all patients at all visits.

Of course, this study has a number of limitations. First, the duration of vit D deficiency has not known. Second, improvement of the parameters after vit D supplementation has not compared to controls. Third, our study had a small sample size and the duration of follow up was short. Although a longer follow up could have better characterized the time course of decline again in QoL, fatigue, depression, mobility, strength; significant decline in vit D levels at 3 months are shown.

In conclusion, the present study showed better balance control, muscle strength, less fatigue, and depression, and higher QoL in patients after vit D supplementation in adults. We would recommend evaluating vitamin $\mathrm{D}$ status once a three months. The 300,00o bolus of vit D was well-tolerated and safe. Nevertheless, our results should be confirmed by further long-term follow-up studies with a randomized control group on wider populations to establish definite effectiveness.

\section{Disclosures}

All authors declare no conflicts of interest. No funding or financial support was received.

\section{References}

1. Holick MF. Vitamin D deficiency. N Engl J Med 2007;357:266-81.

2. Rosen CJ. Clinical practice. Vitamin D insufficiency. N Engl J Med 2011;364:248-54.

3. Knutsen KV, Brekke M, Gjelstad S, et al. Vitamin D status in patients with musculoskeletal pain, fatigue and headache: a cross-sectional descriptive study in a multi-ethnic general practice in Norway. Scand J Prim Health Care 2010;28:166-71.

4. Bischoff-Ferrari HA. Relevance of vitamin D in muscle health. Rev Endocr Metab Disord 2012; 13:71-7.

5. Kerr DC, Zava DT, Piper WT, et al. Associations between vitamin D levels and depressive symptoms in healthy young adult women. Psychiatry Res 2015; 227: 46-51.

6. Hamilton B. Vitamin D and human skeletal muscle. Scand J Med Sci Sports 2010;20:182-90.

7. Kjaergaard M, Waterloo K, Wang CE, Almas B, Figenschau Y, Hutchinson MS. Effect of vitamin D supplement on depression scores in people with low levels of serum 25-hydroxyvitaminD: nested case-control study and randomised clinical trial. Br J Psychiatry 2012;5:360-8

8. Mozaffari-Khosravi H, Nabizade L, Yassini-Ardakani SM, Hadinedoushan H, Barzegar K. The effect of 2 different single injections of high dose of vitamin D on improving the depression in depressed patients with vitamin D deficiency: a randomized clinical trial. J Clin Psychopharmacol 2013; 33(3):378-85.

9. Nair R, Maseeh A. Vitamin D: The "sunshine" vitamin. J Pharmacol Pharmacother 2012;3(2):11826.

10. Autier P, Gandini S. Vitamin D supplementation and total mortality: A meta-analysis of randomized controlled trials. Arch Intern Med. 2007;167:1730-7.

11. Holick MF, Binkley NC, Bischoff-Ferrari HA, et al. Evaluation, Treatment, and Prevention of Vitamin D Deficiency: an Endocrine Society Clinical Practice Guideline. J Clin Endocrinol Metab 2011; 96(7):1911-30.

12. Bischoff-Ferrari HA, Giovannucci E, Willett WC, Dietrich T, Dawson-Hughes B. Estimation ofoptimal serum concentrations of 25 -hydroxyvitamin D for multiple health outcomes. Am J Clin Nutr 2006;84(1):18-28.

13. Rejnmark L. Effects of vitamin $D$ on muscle function and performance: a review of evidence from randomized controlled trials. Ther Adv Chronic Dis 2011; 2(1): 25-37. 
14. Cruz-Jentoft AJ, Baeyens JP, Bauer JM, Boirie Y, Cederholm T, Landi F, et al. European Working Group on Sarcopenia in Older People. Sarcopenia: European consensus on definition and diagnosis: Report of the European Working Group on Sarcopenia in Older People. Age Ageing 2010; 39:412-23.

15. Cedric A, Samir H, St' ephane W, Manuel MO, Gustavo D, Duval Guillaume T.Vitamin D and walking speed in older adults: Systematic review and meta-analysis.Maturitas 2017. http://dx.doi.org/10.1016/j.maturitas.2017.07.012

16. Kücükdeveci AA, McKenna SP, Kutlay S, Gürsel Y, Whalley D, Arasil T. The development and psychometric assessment of the Turkish version of the Nottingham Health Profile. Int J Rehab Res 2000;23(1):31-8

17. Hunt SM, McEwen J, McKenna SP. Measuring health status: a new tool for clinicians and epidemiologists. J Roy Coll Gen Pract 1985; 35: 185-8.

18. Podsiadlo D, Richardson S. The timed "up \& go": a test of basic functional mobility for frail elderly persons. J Am Geriatr Soc 1991;39: 142-8.

19. Kear BM, Guck TP, McGaha AL.Timed Up and Go (TUG) Test: Normative Reference Values for Ages 20 to 59 Years and Relationships With Physical and Mental Health Risk Factors. J Prim Care Community Health 2017;8(1):9-13.

20. Giorgetti MM, Harris BA, Jette A. Reliability of clinical balance outcome measures in the elderly. Physio Res Intern 1998; 3(4):274-83

21. Ozerkan KN. The effects of smiling or crying facial expressions on grip strength, measured with a hand dynamometer and the bi-digital O-ring test. Acupunct Electrother Res 2001;26(3):171-86.

22. Beck AT, Ward CH, Mendelson M,Mock J, Erbaugh J. An inventory for measuring depression. Arch Gen Psychiatry 1961:4:561-71.

23. Hisli Sahin N. Use of the Beck Depression Inventory with Turkish University Students: Reliability, validity and Factor Analysis. Turkish J Psychology 1989; 6, 3-13.

24. Yildirim Y, Ergin G. A validity and reliability study of the Turkish Multidimensional Assessment of Fatigue (MAF) scale in chronic musculoskeletal physical therapy patients. J Back Musculoskeletal 2013; 26: 307-16.

25. Beaudart C, Buckinx F, Rabenda V, et al. The effects of vitamin D on skeletal muscle strength, muscle mass, and muscle power: A systematic review and metaanalysis of randomized controlled trials. J Clin Endocrinol Metab 2014; 99: 4336-45.

26. V. Gerodimos. Reliability of handgrip strength test in basketball players. J Human Kinetics 2012; 31: $25-36$.

27. Cruz-Jentoft AJ, Baeyens JP, Bauer JM, Boirie Y, et al. European Working Group on Sarcopenia in Older People. Sarcopenia: European consensus on definition and diagnosis: Report of the European Working Group on Sarcopenia in Older People. Age Ageing 2010; 39:412-23.

28. C. Annweiler, A.M. Schott, G. Berrut, et al. Vitamin D and ageing: neurological issues. Neuropsychobiology 2010; 62: 139-50.

29. Pfeifer M, Begerow B, Minne HW, et al. Vitamin D status, trunk muscle strength, body sway, falls, and fractures among 237 postmenopausal women with osteoporosis. Exp Clin Endocrinol Diabetes 2001; 109: 87-92.

30. Pfeifer M, Begerow B, Minne HW, Abrams C, Nachtigall D, Hansen C. Effects of a short-term vitamin $\mathrm{D}$ and calcium supplementation on body sway and secondary hyperparathyroidism in elderly women. J Bone Miner Res 2000; 15:1113-8.

31. Bischoff HA, Stahelin HB, Dick W. Effects of Vitamin D and Calcium Supplementation on Falls: A Randomized Controlled Trial. J Bone Miner Res 2003;18(2):343-51.

32. Laksmi PW, Setiati S, Oemardi M, Aries W,Siregar P. Correlation Between Vitamin D Concentration and Basic Functional Mobility in Elderly Women. Acta Med Indones 2007; 39(3):112-18.

33. Dawson-Hughes B: Serum 25-hydroxyvitamin D and muscle atrophy in the elderly. Proc Nutr Soc 2012; 71: 46-9.

34. Qutubuddin A, Cifu DX, Adler RA, et al. A pilot study of vitamin D and balance characteristics in middle-aged, healthy individuals. PM R, 2010,2: 23-6.

35. Roy S, Sherman A, Monari- Sparks MJ, Schweiker O, Hunter K. Correction of Low Vitamin D Improves Fatigue: Effect of Correction of Low Vitamin D in Fatigue Study (EViDiF Study). N Am J Med Sci. 2014; 6(8): 396-402. 
36. Amato AA, Brown RH. Muscular distrophies and other muscle diseases. In: Longo DL, Fauci AS, Kasper DL, Hauser SL, Jameson JL, Loscalzo J, editors. Principles of Internal Medicine. 18th ed.Vol.2. New York: McGraw Hill Medical; 2012.p.3488.

37. Mesci M, Mesci N, İçağasığlu A. Association of vitamin D deficiency with fatigue, daytime sleepiness, and physical activity level. Turk J Phys Med Rehab 2016;62(3):222-8.

38. Anglin RE, Samaan Z, Walter SD, McDonald SD. 2013. Vitamin D deficiency and depression in adults: systematic review and meta-analysis. Br J Psychiatry. 202(2):100-7

39. Gowda U, Mutowo MP, Smith BJ, Wluka AE, Renzaho AM. 2015. Vitamin D supplementation to reduce depression in adults: meta-analysis of randomized controlled trials. Nutrition. 31(3):4219.

40. Akyuz G, SanalToprak C, Yagci İ, Giray E,KuruBektasoglu P. The effect of vitamin D supplementation on pain, quality of life, and nerve conduction studies in women with chronic widespread pain. International Journal of Rehabilitation Research 2017, 40( 1):76-83.

41. Abbasnezhad A, Amani R, Hasanvand A, et al. Association of serum vitamin D concentration with clinical symptoms and quality of life in irritable bowel syndrome. J Am Coll Nutr 2018, 25: $1-7$.

42. Andersen MR, Sweet E, Hager S, Gaul M, Dowd F, Standish LJ. Effects of vitamin d use on health related quality of life of breast cancer patients in early survivorship. Integr Cancer Ther 2019; 18:1-12.

43. Alam U, Fawwad A, Shaheen F, Tahir B, Basit A, Malik RA. Improvement in neuropathy specific quality of life in patients with diabetes after vitamin d supplementation. J Diabetes Res 2017; 2017: 7928083. doi: 10.1155/2017/7928083

44. Garland CF, Kim JJ, Mohr SB, Gorham ED, Grant WB, Giovannucci EL, et al. Meta-analysis of allcause mortality according to serum 25-hydroxyvitamin D. Am J Public Health 2014;104(8): 43-50.

45. Francis R, Aspray T, Fraser W, Gittoes N, Javaid K. Vitamin D and Bone Health: A Practical Clinical Guideline for Patient Management. The National Osteoporosis Society. Camerton, Bath:2013. Available from: http://www.nos.org.uk/document.doc?id=1352.

46. P. Pludowski, Holick MF, Grant WB, et al. Vitamin D supplementation guidelines. J Steroid Biochem Mol Biol 2018; 175: 125-35.

47. P. Pludowski, E.Karczmarewiez, Bayer M, et al. Practical guidelines fort he supplementation of vitamin D and the treatment of deficits in Central Europe- recommended vitamin D intakes in the general population and groups at risk of vitamin D deficiency. Endokrynol Pol. 2013; 64(4) 319-27.

48. Gupta N, Farooqui KJ, Mithal A. Effect of oral versus intramuscular vitamin D replacement in apparently healthy adults with vitamin D deficiency. Indian J Endocrinol Metab 2017; 21(1):131-6.

49. Leventis P, Kiely PD. The tolerability and biochemical effects of high dose bolus vitamin D2 and D3 supplementation in patients with vit D insufficiency. Scand J Rheumatol 2009; 38(2):149-53. 